\title{
The Foundation of Islamic Centre of Thailand Made Val- uable Contributions to Thai Society
}

\author{
Tosaporn mahamud., PhD \\ Centre of Islamic Studies \\ Kasem Bundit University, Bangkok
}

\begin{abstract}
The foundation of the Islamic center of Thailand plays a vital role in order to bring diverse Muslim communities in a common place. The center itself is a bridge between Muslims in Thailand and Islamic world. The operational task of the center runs by many organizations through the funds and funds use for different activities for empowerment of Thai society in general and Muslim community in particular. This paper aims to focus on the role of the foundation of the Islamic center of Thailand to the Thai society. This paper also finds out the historical background of the center in term of building structure and design and functions.
\end{abstract}

KeywordsDesign, Empowerment, Islamic, and Society.

\section{Introduction}

Islam is a minority religion in Thailand. The statistics indicate that the Muslim population is between 2.2 million to 7.4 million,( Raphael Israeli,2009) which includes a variety of immigrants from around the world. Muslims in Thailand are mostly the Muslim traders from the Persian Gulf merchants in Malaya Indonesia (Joseph A. Camilleri, Sven Schottmann, 2013) have brought Islam into it. Thailand's Muslim population is culturally and ethnically diverse. The main ethnic immigrants are from China, Pakistan, Bangladesh, Cambodia, Malaysia and Indonesia and among them two-thirds of the Muslims in Thailand belong to Malay ethnic group (Joseph ChinyongLiow, 2009) . In Thailand, the majority of Muslims live in the three southernmost provinces of Yala, Pattani and Narathiwat and the rest live across the country in different spatial manner . The second most populous region of Muslims is Bangkok.

The diversity of Muslims population in Thailand in term of culture and language leads to different faces of Islam in Thailand. In order to bring all faces of Islam in Thailand in a common platform, Thailand has a foundation of Islamic center which also considers a common place of gathering through many activities related to Muslim affairs in Thailand. (Peter Chalk, 2008)

\section{Historical Background of the Founda- tion of Islamic Center of Thailand}

The main founders of the Foundation for Islamic Center of Thailand taken an initiative to establish the center with the objective to build solidarity of Islam in Thailand by establishing a place of religious worship where people from Muslims countries gather and celebrate Islamic ceremonies together.

Originally, majority of Muslims reside in the fields and villages. Each village has a small mosque for the community and there is no combination of solidarity as permanent public place among the neighboring communities of villages. So the Foundation 
of Islamic Center of Thailand is set up in order to meet and celebrate together. This place is also use for worship on the occasion of Friday's prayer and celebrates Islamic New Year together and a meeting place to exchange ideas and organize events related to the world situations and also a place to learn Islam from different fields.

The founder group led by Capt. Tiered Sriyananda who was president and also played a major role in founding the managing committee for applying the name of "Central Mosque of Thailand" in 1954 and granted the land of location and construction of buildings. There are many places has been used but finally established at the present's location. In the year of 1976, the name is changed from the Central Mosque of Thailand to the Foundation of Islamic Center of Thailand in order to operate of the board in the appropriate manner. There was a small investment section in the foundation of president. In this section, there was a provision of funding through the donations. There are many donators from Muslims of India, private people as well as assistance from government. From all these sources, sufficient amount has been collected to make the mosque. The area of 10 rai from trustees has been built and foundation of the building is laid by former Prime Minister, ChomPhonKitikhr who himself presided over since 1971. (Werner Ende,Udo Steinbach, 2005 )

\section{Architecture of the Mosque}

In 1968, a period of transition of universal civilization and that time, Muslims in Bangkok also adjust their worldviews in accordance with the changes occurred and connect with the world along adhering the local culture. Due this, the lifestyles of Muslims in Bangkok influenced which led to the demand of study by Muslims and they graduated from both religious and academic subjects and played very important role in the development and design of the mosque. The mosque was influenced by modern architecture. Muslims want a mosque in the form of a "Community Hub" where perform many activities in order to preserve a cultural identity of a diverse Muslim community in Bangkok. For build this mosque by choosing best architecture being a "House of

God”.(NithiSathāpitānon,BrianMertens, 2012)

An architect Lt. Peter Guiter designed the project of the "Mosque and Islamic Center of Thailand. For this project, the President had taken it as a major national project. This central mosque is built in Thailand for the ministries of many Muslims countries and using building for daily, weekly and annually activities with the large number of people. Due to advancement of technology there was modern touch to construct and in order to have uniqueness of Islamic architecture it required a lot of funds to construct.

After study of Islamic architecture around the world, the mosque was influenced by the Ottoman Empire and the key elements of mosque like arches, domes, and minarets were built by the influence from Iran and India (Mughal) and especially from Central Mosque in Istanbul, Turkey and a Mosque in Isfahan, Iran. Because of the Islamic architecture looks like very elegant with beautiful arches decorated with mosaic patterns and magnificent Arabic calligraphy which is difficult to imitate and for that it was required skilled technicians and enormous amount of money. 
Proc. of the Third Intl. Conf. Advances in Social Science, Economics and Management Study- SEM 2015 Copyright (C) Institute of Research Engineers and Doctors, USA .All rights reserved.

ISBN: 978-1-63248-063-7doi: 10.15224/ 978-1-63248-063-7-39
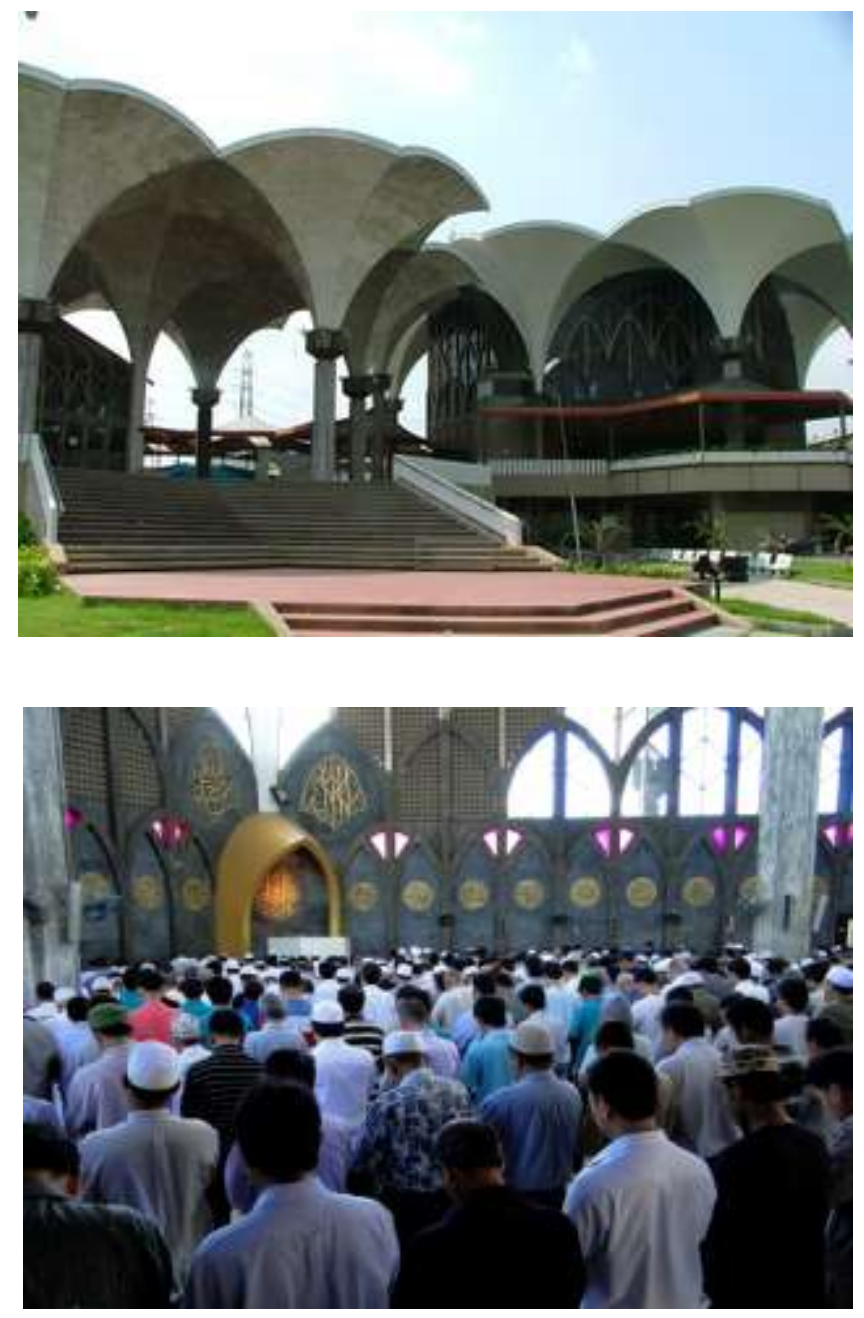

Jumat praying

With the limited budget of about 2-3 million to construct the Mosque of the Islamic Center of Thailand decided to start. The model of design was prepared with a Modular system in which the shape of roof of a unit was hexagonal. Each unit was constructed with a beautiful composition and arrangement in a hexagon shape and there were 19 units of same shape of hexagon. There is a

\section{Jumu'ah on Friday}

pole in the center which looks like six petal like flowers blooming and hold with a sun. The structure of each unit is separate and connected to each other. The material used for each unit was a concrete shell with the width of 12 meters. The ceiling of the building is an arch shape which looks like soft, slender and curved lines converging in a new dimension and also without use of paints.
In order to establish the identity of the Islamic architecture of the building and mosque, the pattern of Moresque, black Arabian down walls and doors, railings fences, stained glasses as well as Arabic calligraphy on black marble walls on the western side of Gibraltar used. There are 21 panels for a ventilation system in this building in order to help the building without air conditions. The system of natural ventilation is there due to very high of the ceiling in the building. At the top there is gently hot air floating and at the same natural wind blowing below at the gates. The curvature of the roof makes indoor air circulation which gives coolness while any times of pray.

The capacity of the mosque of the Islamic Center of Thailand is for 5,000 people including praying for men and women both. There is a hexagon shape conference center which has capacity of 25 VIP seats apart from audience. At the downstairs, there are a living room, office of trustee and a hall of 1000 people capacity for meetings and seminars and this hall use for weddings and private functions of Muslim people. There is also a public library, a corporate office and offices of Muslims organizations and foundations. There is a space for ablution and also has separate restrooms for men and women. The hall also use for fasting during the month of Ramadan and lectures.

The philanthropic vision of the Islamic Center of Thailand is to learn and enhance the understanding of Islam as well as through activities improve the lives of Muslims. This center cooperates with NGOs and organizations of Thailand Social Development and organizes Muslim congregations.

\section{The zakat policy of the Islamic Center}

The system of Zakat, purifies the taxation of income and wealth of a Muslim. It is a form of obligatory alms giving, and the collected amount is 


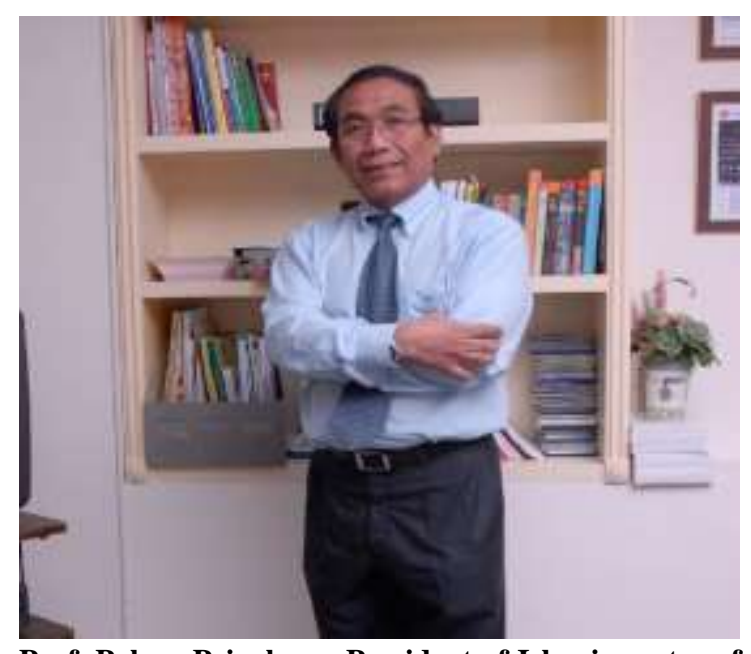

Prof. PakornPriyakorn, President of Islamic centre of Thailand

paid to poor Muslims, to zakat collectors, to new converted people to Islam, as income to its clergy, and others. Zakat is mandatory for all Muslims, on their income and wealth above a minimum amount called nisab. However, there are disagreements among Islamic scholars on nisab and various aspects of zakat. Sharia mandates it as a requirement and evidence of being a Muslim. The payment and disputes on zakat have played a major role in the history of Islam, such as the Ridda wars that fueled the conflict between the Sunni and Shia sects of Islam.

The practice of Zakat is one of the Five Pillars of Islam, and it is the only pillar which enjoins Muslims to submit to Islamic statism. The zakat is considered by Muslims to be an act of piety through which one expresses concern for the wellbeing of fellow Muslims, as well as preserving social harmony between the wealthy and the poor. Zakat promotes a more equitable redistribution of wealth and fosters a sense of solidarity amongst members of the Ummah. (Benda-Beckmann, Franz von, 2007)

Under the Zakat policy of the Islamic center of Thailand, there is a committee to research the preparation of Muslim Aid Fund and helping to needed and suffering people and also use the fund in the framework of Islamic principles related to clarity. The administration under this policy with full of transparency and accountability in order to collect fund from various organizations and by philanthropists and distribute according to religious custom. The success of administration is possible if there is distribution of fund into

social order in proper manner means with a set of guideline. The working system is bordered if accounting and auditing go with Islamic law in order to reports carry out in effective manner.

\section{The mission of the Foundation for Is- lamic Center of Thailand}

The foundation of the Islamic center of Thailand aims to develop the Muslim Society through the development center and the center of learning. This center coordinates and cooperates with private organizations of Muslim countries in order to develop IP activities and donations to centers for strengthening religious relations and congregations talk for Thai society and also develop the availability and adequacy for religious, social and cultural activities for the Muslim community. This kind of platform provide funds for making mosques, large auditoriums, meeting rooms, offices, food courts and other facilities. There is ZSA fund for administration and charity for kids, orphans and subsidize in educational activities for poor Muslims. For professional development of Muslims there are funds which allocate and regulate on the principles of Zakat.

There are funding form government and private organizations including the donations of individual and public charitable organizations of Muslims countries to be used to construct of the Islamic Cultural Center and subsidizing on the various aspects of the foundation like learning man- 
agement studies, seminars, trainings, and workshops to improve knowledge and promote the exchange of ideas among Muslims. And also discuss on the issues of social development and improve the lives of Muslims including the enhance the information of Islam and its connection with the Muslim world. This center coordinates with Muslim organizations of the country in order to improve relations, cooperation and support to Muslims in Thailand and strengthen the culture.

The Islamic center is a hub of activities which benefit to public through many public conversations like radio and television programs. The programs on the current events benefit to society which are potential of the Islamic center in Thailand. ( $\mathrm{Pa}$ kornPriyakorn )

\section{The strategy of the Foundation of the Islamic Center of Thailand}

There are policies relating to activities of the foundation including strategy, development and maintenance of the premises to benefit. The foundation provides fully develop schemes for utilities specially sanitation of the ETA area.

The center develops the fund of Zsa to create the Muslim Brotherhood in terms of their quality of life, development, fundraising platform, use donations for various activities and help to make a network to link with Osaka funds for different organizations. In term of developing the learning, a center for Islamic studies has started. There is also establishment of a library and Human Development Center in order to dissemination of Islamic based moral knowledge for benefiting to society and also establishment of Information centers to connect Muslims of Thailand and Islamic world.

The Muslim organizations develop a network between Thailand and abroad in order to develop the
Muslim community and promote the role of women, youth and families through activities and promote the cooperation between Muslim communities and organizations in Thailand and also to enhance partnering Muslims of the country and envoy of the Arab countries. The development of centers related to social welfares and promotes the freedom of Muslims with the help of media.

The foundation of the Islamic center of Thailand develops the relationships among civil society, public and private organizations and empowerment the civil society through congregational activities and to develop new religious right in the society. This center provides the knowledge of Islam to the public, private and other organizations in order to finish wrong perception of Islam and for Muslims. The aim of this center is to create social peace and harmony through the different activities with involvement of people.

This center has been widely supported and always to invite to those who are interested to help and work for the Islamic center in the capacity of various committees and sub-committees appoint by the foundation and the terms of the committees and sub-committees are for three years. (FICT, 2014)

\section{Conclusion}

In conclusion, the foundation of the Islamic center of Thailand is a very important place for Muslims in Thailand which runs the affairs related to lives of the Muslim community for their welfare and at the same time builds strong relationships among different organizations like public, private and others. This center also gives benefit to the nation in terms of helping the poor, orphan, and widows and brings moderation space in the Muslim community. This center develops strong bonds among Muslims countries and generates funds for 
betterment of the society and creates peace and harmony in Thailand.

\section{References}

[1] Benda-Beckmann, Franz von (2007), Social security between past and future: Ambones networks of care and support,LIT Verlag, Münster. p. 167.

[2] Joseph A. Camilleri,SvenSchottmann ( 2013) Culture, Religion and Conflict in Muslim Southeast Asia, 711 Third Avenue, New York, NY 10017.

[3] Joseph ChinyongLiow( 2009), ,Islam, Education, and Reform in Southern Thailand: Tradition \& Transformation, Institute of Southeast Asian Studies, Singapore.

[4] NithiSathāpitānon,BrianMertens (2012), Architecture of Thailand: A Guide to Traditional and Contemporary Forms, Singapore.

[5] PakornPriyakor (2014), Development Strategy and Management Plan 2014-2020, The Foundation of the Islamic Center of Thailand, Bangkok.

[6] PakornPriyakorn, The Status of Islam and Muslims in Thailand,

Retrieved from,http://www.muis.gov.sg/cms/uploadedFiles/Muis Academy/Pages/Online/Articles/The\%20Status\%20of\%20Isla m\%20and\%20Muslims\%20in\%20Thailand.pdf.

[7] Peter Chalk (2008),The Malay-Muslim Insurgency in Southern Thailand: Understanding the Conflict, Rand Corporation, Santa Monica, CA.

[8] Raphael Israeli (2009), Muslim Minorities in Modern States: The Challenge of Assimilation, New Brunswick, New Jersey USA.

[9] Werner Ende,Udo Steinbach (2005), Islam in the World Today: A Handbook of Politics, Religion, Culture, and Society, Der Islam in Der Gegenwart, $5^{\text {th }}$ Edition, by Werner Ende and Udo Steinbach, Verlag, Beck oHG, Munchen, 